\title{
Analisis Tinggi Muka Air Daerah Genangan Banjir Rob Sungai Banjirkanal Barat Bagian Hilir Menggunakan Software HEC-RAS
}

\author{
Rahmat Harta K ${ }^{1}$, Prambudi Terrano ${ }^{2}$, Budi Santosa ${ }^{3}$ \\ e-mail: ${ }^{1}$ rahmatharta@gmail.com, ${ }^{2}$ prambuditerrano@gmail.com
}

Program Studi Teknik Sipil, Fakultas Teknik, Universitas Katolik Soegijapranata; Jl. Pawiyatan

Luhur IV No. 1 Bendan Dhuwur Semarang, telp: (024) 8441555

\begin{abstract}
Abstrak
Banjir merupakan bencana alam yang sejatinya dapat diminimalisir dampaknya ataupun bisa dihindari jika tahu sumber permasalahannya. Kenaikan debit banjir sebagian besar dipengaruhi oleh adanya perubahan tata guna lahan pada Daerah Aliran Sungai (DAS), dan bentuk profil sungai yang tidak dapat menampung debit banjir yang terjadi disetiap periodenya. Tujuan penelitian ini adalah mengetahui luas genangan yang terjadi akibat limpasan dari sungai banjirkanal barat pada daerah yang tergenang rob, serta memberikan solusi alternatif mengatasi dan meminimalisir terjadinya banjir. Data yang diperlukan berupa data curah hujan harian dari tahun 2005 - 2017 di lima stasiun hujan, yaitu Stasiun Madukoro, Stasiun Simongan, Stasiun Kalisari, Stasiun Gunungpati, dan Stasiun Sumur Jurang. Hasil dari penelitian ini adalah luas area genangan periode ulang 2 tahunan sebesar $1.461 .331 \mathrm{~m} 2$ dan tinggi muka air banjir antara $1,17 \mathrm{~m}$ sampai 4,52 $\mathrm{m}$. Luas area genangan periode ulang 5 tahunan sebesar $1.841 .309 \mathrm{~m} 2$ dan tinggi muka air banjir antara 1,67 m sampai 4,8 m. Luas area genangan periode ulang 10 tahunan sebesar $2.455 .585 \mathrm{~m} 2$ dan tinggi muka air banjir antara 2,01 $\mathrm{m}$ sampai 5,01 m. Luas area genangan periode ulang 25 tahunan sebesar $2.681 .935 \mathrm{~m} 2$ dan tinggi muka air banjir antara 2,32 m sampai 5,2 m. Luas area genangan periode ulang 50 tahunan sebesar $3.579 .047 \mathrm{~m} 2$ dan tinggi muka air banjir antara 2,47 m sampai 5,28 m. Luas area genangan periode ulang 100 tahunan sebesar $5.131 .457 \mathrm{~m} 2$ dan tinggi muka air banjir antara 2,56 m sampai 5,34 m. Dari permodelan tersebut dapat diketahui pada bagian mana yang terjadi limpasan. Maka dari itu dilakukan solusi altermatif berupa normalisasi sungai.
\end{abstract}

Kata kunci: Daerah Aliran Sungai (DAS), HEC-HMS, HEC-RAS, Luas Genangan

\begin{abstract}
Floods are natural disasters that can actually be minimized or can be avoided if you know the source of the problem. The increase in flood discharge is largely influenced by changes in land use in the watershed (DAS), and river profile forms that cannot accommodate the flood discharge that occurs in each period. The purpose of this study was to determine the area of inundation that occurs due to runoff from the western banjir river in the flooded area, and provide alternative solutions to overcome and minimize the occurrence of flooding. Data needed in the form of daily rainfall data from 2005 2017 at five rain stations, namely Madukoro Station, Simongan Station, Kalisari Station, Gunungpati Station, and Sumur Jurang Station. The results of this study are the 2-year return period inundation area of 1,461,331 m2 and flood water level between $1.17 \mathrm{~m}$ to $4.52 \mathrm{~m}$. The area of the 5-year return period inundation is 1,841,309 $\mathrm{m} 2$ and the flood water level is between $1.67 \mathrm{~m}$ and $4.8 \mathrm{~m}$. The total inundation area of the 10-year return period is 2,455,585 $\mathrm{m} 2$ and the flood water level is between $2.01 \mathrm{~m}$ and $5.01 \mathrm{~m}$. The total inundation area of the annual return period is 2,681,935 $\mathrm{m} 2$ and the
\end{abstract}


flood water level is between $2.32 \mathrm{~m}$ to $5.2 \mathrm{~m}$. The total inundation area of the 50-year return period is 3,579,047 $\mathrm{m} 2$ and the flood water level is between $2.47 \mathrm{~m}$ to $5.28 \mathrm{~m}$. The 100-year return period inundation area is 5,131,457 $\mathrm{m} 2$ and the flood water level is between $2.56 \mathrm{~m}$ and $5.34 \mathrm{~m}$. From the modeling it can be seen where the runoff occurred. So from that, alternative solutions were made in the form of river normalization.

Keywords: Watershed (DAS), HEC-HMS, HEC-RAS, Inundation Area

\section{PENDAHULUAN}

\subsection{Latar Belakang}

Sungai merupakan salah satu sumber daya air yang banyak dimanfaatkan untuk memenuhi kebutuhan air setiap makhluk hidup. Salah satu sumber air dari sungai adalah air hujan.

Indonesia tercatat memiliki lebih dari 500 sungai besar dan kecil, 30\% diantaranya melewati kawasan padat penduduk, yang berpotensi menimbulkan banjir pada wilayah tersebut. (Depkes RI, 2006). Apabila sudah memasuki musim penghujan, beberapa daerah di Indonesia mengalami musibah banjir. Salah satu faktor penyebab terjadinya musibah banjir adalah volume air yang sangat besar dan tidak dapat ditampung oleh penyimpan air yang ada di daerah tersebut.

Kota Semarang adalah satu diantara kota - kota besar di Indonesia dan menjadi Ibu Kota Jawa Tengah. Luas daerah administrasi $363,4 \mathrm{~km} 2$ terdiri dari 16 Kecamatan dan 177 Kelurahan, mempunyai letak geografis yang strategis sebagai pusat pemerintahan. Beberapa Kelurahan selain letaknya yang berada di tepi Pantai Jawa juga letaknya berada di sepanjang arah aliran Sungai Semarang, dimana Kelurahan-Kelurahan ini sering dilanda genangan banjir (Astuti, 2009). Sungai Banjirkanal Barat merupakan salah satu sungai terpanjang yang membelah Kota Semarang yang digunakan sebagai drainase kota.

Keseluruhan area tangkapan kira-kira 204 $\mathrm{km}^{2}$, yang termasuk area tangkapan $70 \mathrm{~km}^{2}$ untuk sungai Kreo (panjang sungai berkisar $10 \mathrm{~km}$ ) dan $34 \mathrm{~km}^{2}$ untuk Sungai Kripik (panjang sungai berkisar $12 \mathrm{~km}$ ). Satuan Wilayah Sungai (SWS) Sungai Banjirkanal Barat Semarang meliputi wilayah seluas \pm 11.946,26 Ha. Pada daerah utara Kota Semarang sering terjadi Rob, dtambah dengan seringnya terjadi limpasan dari sungai Banjirkanal Barat. Diperlukan evaluasi untuk mengurangi dampak yang terjadi akibat terjadinya rob dan limpasan yang terjadi.

\subsection{Rumusan Masalah}

Meluapnya sungai Sungai Banjirkanal Barat pada daerah tergenang rob mengakibatkan dampak yang merugikan. Diperlukan evaluasi untuk mengurangi dampak yang terjadi akibat terjadinya rob dan limpasan yang terjadi.

\subsection{Tujuan Penelitian}

Tujuan dari penelitian ini adalah sebagai berikut:

a. Untuk mengetahui debit dan tinggi muka air banjir rob Sungai Banjirkanal Barat bagian hilir.

b. Untuk mengetahui luas daerah genangan banjir rob maksimum Sungai Banjirkanal Barat bagian hilir.

\section{TINJAUAN PUSTAKA 2.1 Siklus Hidrologi}

Siklus Hidrologi adalah gerakan air laut ke udara, yang kemudian jatuh ke permukaan tanah lagi sebagai hujan atau bentuk presipitasi lain, dan akhirnya mengalir ke laut kembali. 


\subsection{Hujan}

Daerah aliran sungai (DAS) adalah daerah yang dibatasi oleh punggungpunggung / pegunungan dimana air hujan yang jatuh didaerah tersebut akan mengalir menuju sungai utama pada suatu titik/stasiun yang ditinjau (Triatmodjo, 2010).

\subsection{Sungai}

Sungai atau saluran terbuka menurut Triatmodjo (2010) adalah saluran dimana terdapat air mengalir dengan muka air bebas. Pada saluran terbuka, misalnya sungai (saluran alam), variabel aliran sangat tidak teratur terhadap ruang dan waktu.

\subsection{Muara Sungai}

Muara sungai adalah bagian hilir dari sungai yang berhubungan dengan laut. Permasalahan di muara sungai dapat ditinjau dibagian mulut sungai (river mouth) dan estuari.

\subsection{Rob dan Pasang}

Banjir pasang air laut atau disebut rob adalah merupakan banjir yang terjadi akibat pasang air laut yang menggenangi kawasan yang mempunyai ketinggian lebih rendah dari permukaan air laut. Banjir pasang air laut (rob) adalah pola fluktuasi muka air laut yang dipengaruhi oleh gaya tarik benda-benda angkasa, terutama oleh bulan dan matahari terhadap massa air laut di Bumi (Sunarto, 2003).

\subsection{Hujan}

Menurut Triatmodjo (2010) hujan adalah bentuk presipitasi berbentuk air dari atmosfer yang jatuh sampai ke permukaan bumi; yang bisa berupa hujan, hujan salju, kabut, embun dan hujan es.

\subsubsection{Pemilihan Jenis Distribusi}

a. Distribusi Gumbel (Soemarto, 1999)

$$
X_{T}=\bar{X}+\frac{S}{S_{n}}\left(Y_{T}-Y_{n}\right)
$$

b. Distribusi Log Person III Soewarno (1995)

$$
C_{S}=\sqrt{\frac{n \sum(\log X i-\overline{\log X})^{3}}{(n-1)(n-2) S^{3}}}
$$

$$
\log X_{i}=\overline{\log X}+K_{T} \times S
$$

\subsubsection{Pengujian Kecocokan Distribusi}

Pengujian kecocokan sebaran digunakan untuk menguji apakah sebaran tersebut dapat memenuhi syarat untuk data perencanaan. Pengujian kecocokan dapat dilakukan 2 cara.

a. Perhitungan Chi Kuadrat

b. Perhitungan Smirnov Kolmogorov

\subsection{Banjir}

Satu definisi banjir menurut Suripin (2004) adalah suatu kondisi di mana tidak tertampungnya air dalam saluran pembuang (palung sungai) atau terhambatnya aliran air di dalam saluran pembuang, sehingga meluap menggenangi daerah (dataran banjir) sekitarnya.

\subsection{Model Hidrologi}

Hydrologic Engineering Centre (HEC) - Hydrologic Modeling System (HMS) merupakan salah satu model hidrologi yang masuk dalam kategori model matematik yang dikembangkan oleh Hydrologic Engineering Centre (HEC) dari US Army Corps Of Engineers (Arlen, 2000).

\subsection{Model Hidraulika}

HEC-RAS adalah singkatan dari Hydraulic Engineering Centre-River Analysis System. HEC-RAS merupakan program aplikasi yang didesain untuk 
memodelkan aliran di sungai, Program River Analysis System (RAS), yang dibuat oleh Hydrologic Engineering Center (HEC) yang merupakan satu divisi di dalam Institute for Water Resources (IWR), di bawah US Army Corps of Engineers (USACE). HEC-RAS merupakan model satu dimensi aliran permanen maupun tak permanen (steady and unsteady onedimensional flow model) (Istiarto, 2014).

\section{METODE PENELITIAN}

\subsection{Lokasi Penelitian}

Lokasi yang diambil pada penelitian ini adalah Sungai Banjirkanal Barat yang berada di Kota Semarang Provinsi Jawa Tengah. Pada penelitian ini dimulai dari hulu Sungai Banjirkanal Barat hingga ke hilir Sungai Banjirkanal Barat. Hulu dari Sungai Banjirkanal Barat merupakan kelanjutan dari ruas kali Garang yang mengalir dari gunung Ungaran ke Utara pada pertemuan 2 cabang utama yaitu Sungai Kripik dan Sungai Kreo, masingmasing kurang lebih $12 \mathrm{~km}$ dan $10 \mathrm{~km}$ dihitung dari hulu ke mulut sungai. Penelitian dilakukan di Laboratorium Bahan Bangunan Program Studi Teknik Sipil Fakultas Teknik Unika SOEGIJAPRANATA. Waktu pelaksanaan Tugas Akhir dilaksanakan selama 6 bulan dari 30 September 2017 hingga 30 Maret 2018.

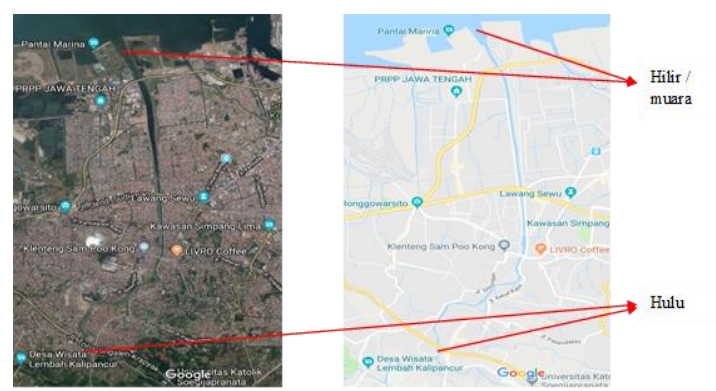

Gambar 3.1 Lokasi Penelitian

\subsection{Tahapan Penelitian}

Analisis dilakukan dalam beberapa tahapan, yaitu:

1. Siapkan data yang akan diolah

a. Curah hujan harian maksimum

b. Data geometri Sungai Banjirkanal Barat

2. Penentuan batas DAS dan membagi menjadi Sub DAS.

3. Penentuan area Poligon Thiessen.

4. Penentuan distribusi hujan rancangan.

5. Penentuan parameter awal yang digunakan
a. Curve number $(\mathrm{CN})$
b. Impervious $(\%)$
c. Lag time.

6. Hitung besar debit puncak banjir lapangan.

7. Input data parameter awal kedalam software HEC-HMS.

8. Kalibrasi parameter awal dan didapatkan debit puncak banjir simulasi.

9. Penentuan parameter awal yang digunakan pada HEC-RAS.
a. Geometri saluran sungai
b. Nilai kekerasan manning
c. Data aliran untuk analisis hidrologi

10. Input data geometri dan debit rencana Kedalam software HEC-RAS.

11. Running Digital Elevation Model untuk mencari luas genangan..

12. Hitung luas wilayah genangan.

13. Analisis Sungai Banjirkanal Barat kondisi eksisting terhadap debit banjir dan luas genangan.

14. Memberikan solusi alternatif. 


\subsection{Diagram Alir}

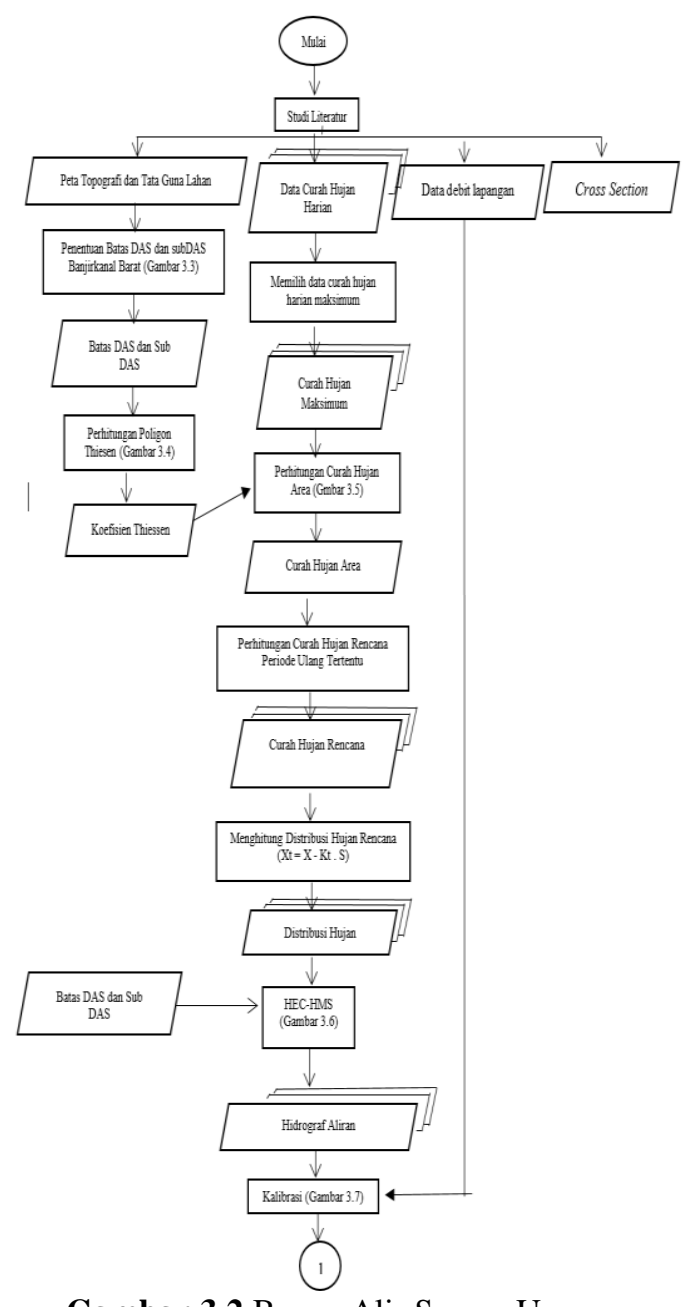

Gambar 3.2 Bagan Alir Secara Umum

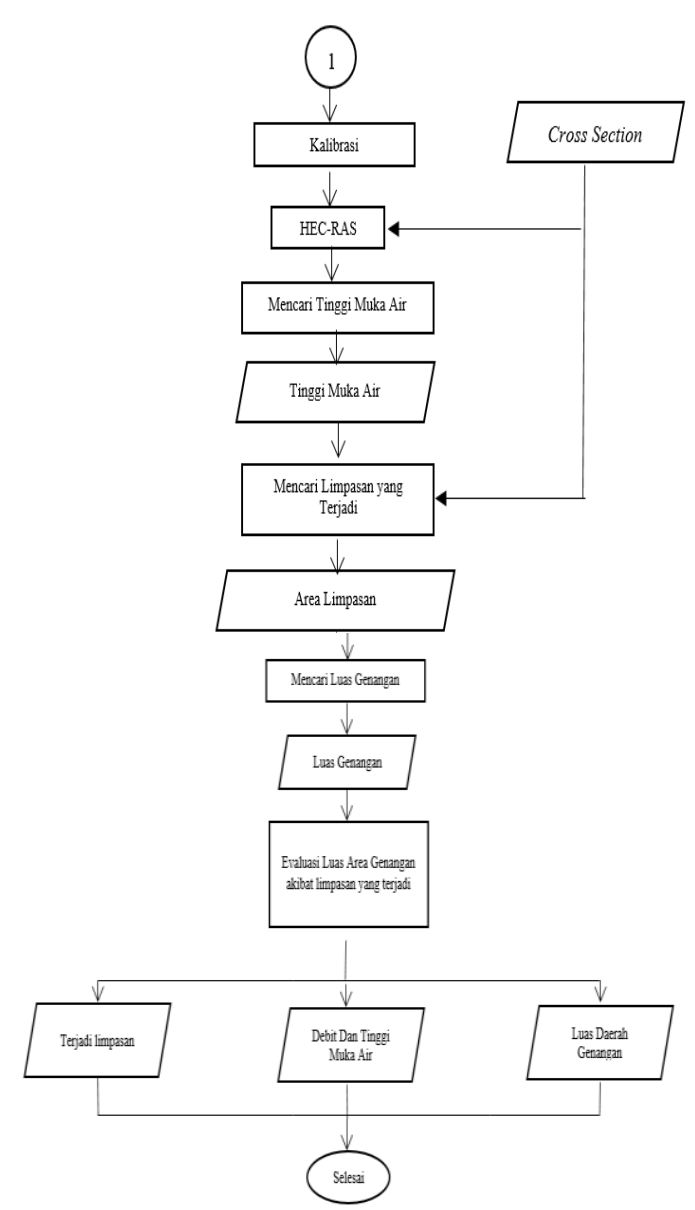

Gambar 3.2 Bagan Alir Secara Umum (Lanjutan)

\section{HASIL DAN PEMBAHASAN}

Setelah dilakukan pengolahan data distribusi hujan jam-jaman dan karakteristik DAS Banjirkanal Barat, selanjutnya dapat dilakukan simulasi debit puncak banjir menggunakan software HEC-HMS. Hasil dari simulasi menggunakan HEC-HMS berupa besar debit puncak banjir yang selanjutnya dapat di gunakan untuk input data software HEC-RAS. Setelah melakukan simulasi dengan debit banjir rencana maka diketahui bahwa kapasitas Sungai Banjirkanal Barat tidak dapat cukup menampung air, dimana air diharuskan tidak melebihi kapasitas penampang. Dalam kajian ini solusi alternatif yang dilakukan adalah berupa normalisasi sungai. 


\subsection{Analisis Debit Puncak Banjir Hasil Output Software HEC-HMS}

Setelah dilakukan seluruh tahapan dalam software HEC-HMS, maka dilakukan simulation run sehingga mendapatkan data output berupa peak discharge (debit puncak) dengan periode ulang tertentu yaitu 2 tahunan, 5 tahunan, 10 tahunan, 25 tahunan, 50 tahunan, dan 100 tahunan.

Tabel 4.1 Debit Banjir Rencana Sungai Banjirkanal Barat

\begin{tabular}{|c|c|}
\hline Periode Ulang & Debit Banjir \\
\hline 2 Tahunan & $169,9 \mathrm{~m}^{3} / \mathrm{s}$ \\
\hline 5 Tahunan & $268,0 \mathrm{~m}^{3} / \mathrm{s}$ \\
\hline 10 Tahunan & $348,0 \mathrm{~m}^{3} / \mathrm{s}$ \\
\hline 25 Tahunan & $426,7 \mathrm{~m}^{3} / \mathrm{s}$ \\
\hline 50 Tahunan & $465,9 \mathrm{~m}^{3} / \mathrm{s}$ \\
\hline 100 Tahunan & $492,7 \mathrm{~m}^{3} / \mathrm{s}$ \\
\hline
\end{tabular}

Berdasarkan tabel 4.1 dapat dilihat peningkatan debit puncak banjir dari periode 2 tahunan sampai periode 100 tahunan.

\subsection{Simulasi Model HEC-RAS}

Setelah dilakukan seluruh tahapan dalam software HEC-RAS, maka dilakukan simulation run sehingga dapat diketahui bentuk penampang sungai, tinggi muka air dan kapasitas Sungai Banjirkanal Barat mencukupi atau tidak, contoh hasil output dari simulasi HEC-RAS dengan periode ulang 100 tahunan dapat dilihat pada Gambar dibawah ini.

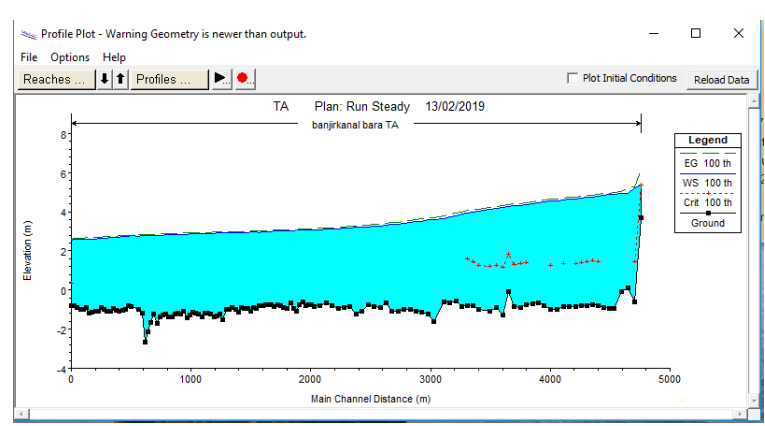

Gambar 4.1 Profil Muka Air Eksisting terhadap Debit Banjir Rencana 100 tahun

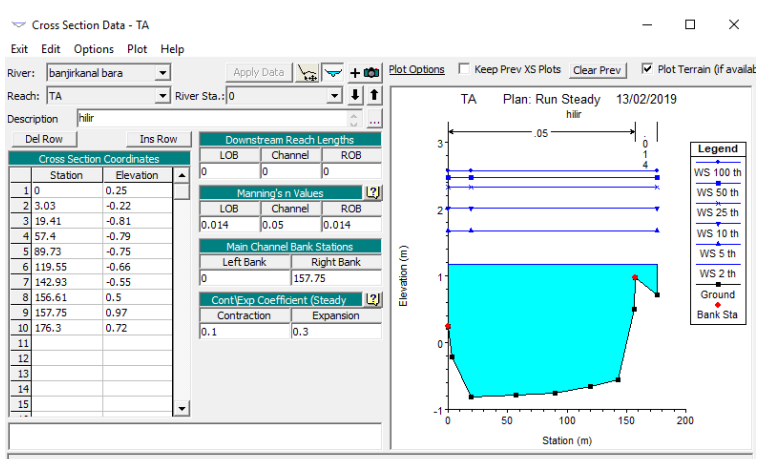

Gambar 4.2 Hasil Output HEC-RAS terhadap Debit Banjir Rencana 100 Tahun

Hasil Output HEC-RAS menunjukan profil muka air akibat debit rencana 100 tahunan dapat dilihat pada Gambar 4.1 sedangkan Gambar 4.2 menunjukan hasil simulasi HECRAS pada cross section akibar debit banjir rencana 100 tahunan.

\subsection{Analisis Daerah Genangan Banjir Rob Hilir Sungai Banjirkanal Barat}

Setelah melakukan analisis dengan menggunakan software HEC-RAS maka diperoleh hasil berupa luas genangan menurut periode ulangnya. Untuk menentukan luas genangan yang terjadi yaitu setelah dilakukan proses running pada software HEC-RAS kemudian menggunakan bantuan google earth. Untuk mencari genangan dapat diketahui langsung menggunakan software HEC-RAS. Karena cakupan wilayah untuk proses running memiliki batas cakupan area minimal, dan untuk wilayah lokasi penelitian terbilang kurang dari cakupan minimal maka tidak dapat dilakukan proses running untuk mengetahui secara langsung genangan yang terjadi.

Dengan proses manual menggunakan garis kontur dan konsep batas DAS maka luas daerah genangan yang terjadi dapat diketahui dengan bantuan google earth sekaligus besar genangan yang terjadi. Berikut adalah hasil analisis luas daerah genangan banjir menurut periode ulangnya. 


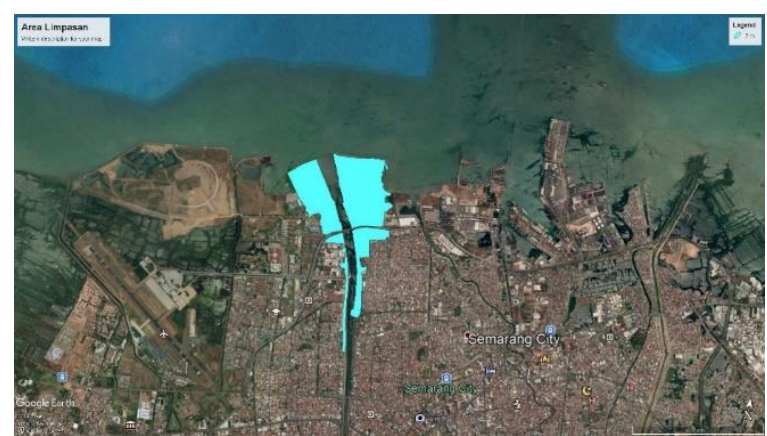

Gambar 4.3 Luas Genangan Periode Ulang 2 Tahunan

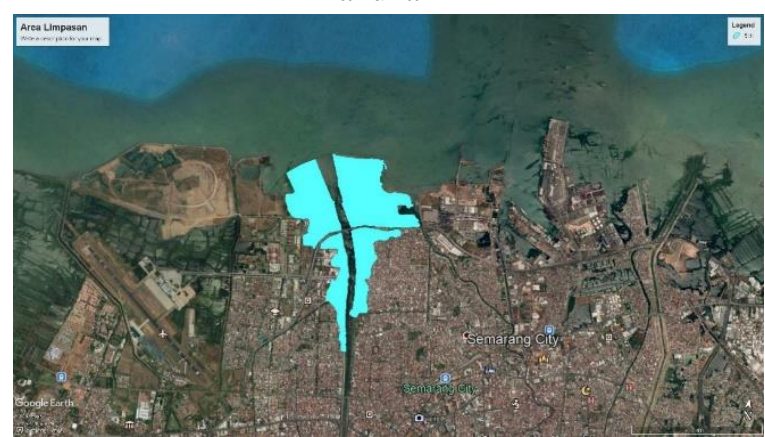

Gambar 4.4 Luas Genangan Periode Ulang 5 Tahunan

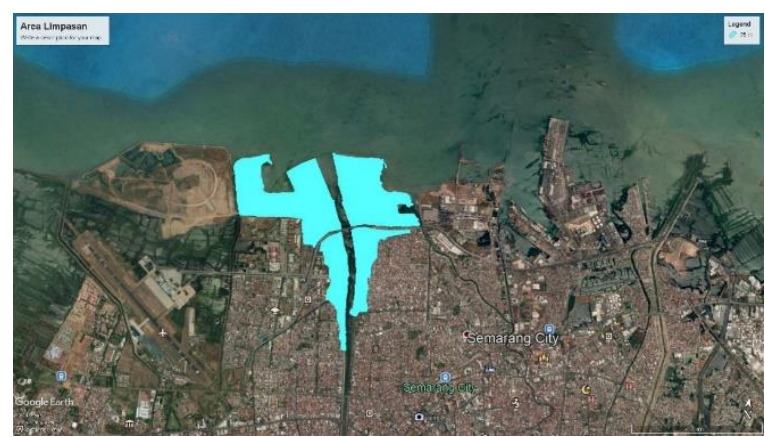

Gambar 4.5 Luas Genangan Periode Ulang 10 Tahunan

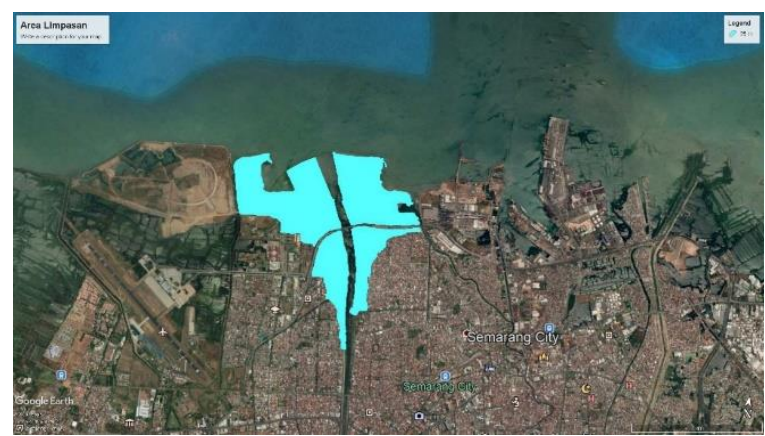

Gambar 4.6 Luas Genangan Periode Ulang 25 Tahunan

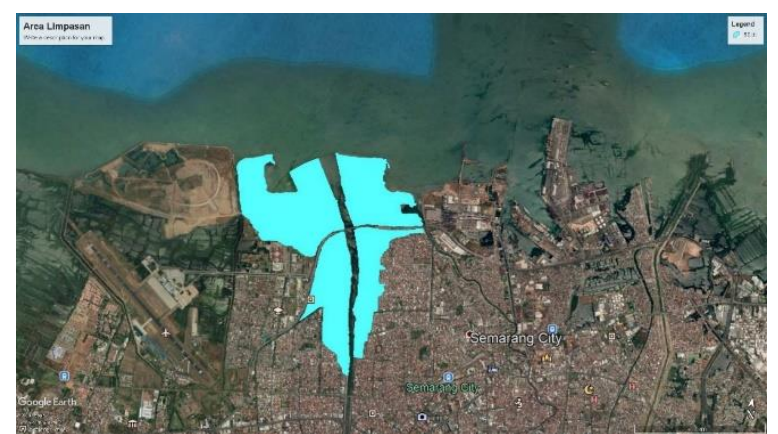

Gambar 4.7 Luas Genangan Periode Ulang 50 Tahunan

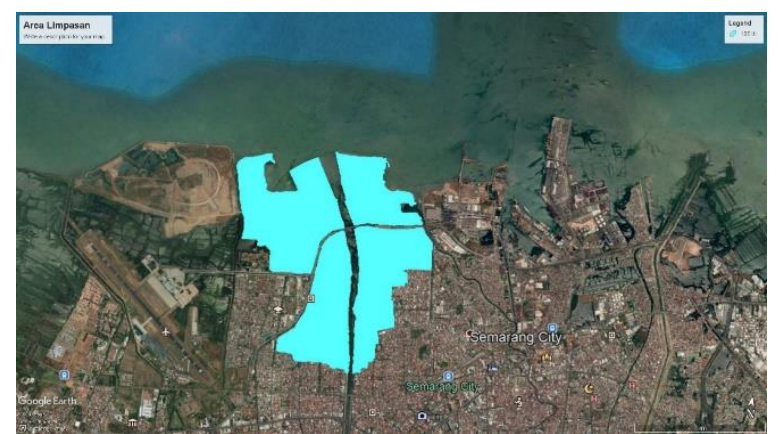

Gambar 4.8 Luas Genangan Periode Ulang 100 Tahunan

\section{KESIMPULAN DAN SARAN}

\subsection{Kesimpulan}

Berdasarkan hasil perhitungan dan analisis dapat diambil beberapa kesimpulan sebagai berikut:

1. Debit rencana periode ulang $2,5,10,25,50$, 100 tahunan adalah $169,9 \mathrm{~m}^{3} / \mathrm{det}, 268$ $\mathrm{m}^{3} /$ det, $348 \mathrm{~m}^{3} /$ det, $426,7 \mathrm{~m}^{3} /$ det, 465,9 $\mathrm{m}^{3} /$ det, $492,7 \mathrm{~m}^{3} /$ det.

2. Tinggi muka air banjir minimum periode ulang 2, 5, 10, 25, 50, 100 tahunan adalah $1,17 \mathrm{~m}, 1,67 \mathrm{~m}, 2,01 \mathrm{~m}, 2,32 \mathrm{~m}, 2,47 \mathrm{~m}, 2,56$ $\mathrm{m}$. Sedangkan tinggi muka air banjir maksimum periode ulang $2,5,10,25,50$, 100 tahunan adalah $4,52 \mathrm{~m}, 4,8 \mathrm{~m}, 5,01 \mathrm{~m}$, $5,2 \mathrm{~m}, 5,28 \mathrm{~m}, 5,34 \mathrm{~m}$.

3. Luas genangan periode ulang $2,5,10,25,50$, 100 tahunan adalah $1.461 .331 \mathrm{~m}^{2}, 1.841 .309$ $\mathrm{m}^{2}, 2.455 .585 \mathrm{~m}^{2}, 2.681 .935 \mathrm{~m}^{2}, 3.579 .047$ $\mathrm{m}^{2}, 5.131 .457 \mathrm{~m}^{2}$. 


\subsection{Saran}

Dari beberapa kesimpulan di atas dapat dikemukakan saran-saran sebagai berikut:

1. Perlu dilakukan normalisasi dan perencanaan suatu program ataupun metode untuk mengantisipasi dan meminimalisir dampak apabila rob serta terjadi limpasan dari sungai Banjirkanal Barat secara bersamaan.

2. Untuk mengantisipasi atau meminimalisir dampak yang terjadi akibat limpasan dabat berupa pembuatan embung untuk mengatur dan menampung suplai aliran air hujan serta untuk meningkatkan kualiitas air di badan air yang terkait (sungai, danau), mencegah banjir dan pengairan. Pembuatan biopori yang berguna sebagai resapan.

3. Adanya perawatan atau maintenance secara berkala sehingga fasilitas untuk menjaga kualitas air dalam meminimalisir terjadinya limpasan atau banjir tetap berfungsi optimal.

\section{DAFTAR PUSTAKA}

Astuti, Sri. 2009. Reklamasi Tipologi Bangunan dan Kawasan Akibat Pengaruh Kenaikan Muka Air Laut di Kota Pantai Semarang. Departemen Kimpraswil. Bandung.

Departemen Kesehatan Republik Indonesia. $2006 . \quad$ Banjir. Jakarta: http://www.depkes.go.id/development/ site/jkn/index.php?cid=13010400004 \&id=buku-banjir-2006. Diakses pada tanggal 10 Mei 2018.

Istiarto. 2014. Modul Pelatihan Simulasi Aliran 1-Dimensi Dengan Bantuan Paket Program Hidrodinamika HECRAS. Universitas Gadjah Mada.

Soemarto, CD. 1999. Hidrologi Teknik. Jakarta : Erlangga.
Soewarno. 1995. Hidrologi Aplikasi Metode Statistik Jilid 1. Bandung: Nova.

Sunarto. 2003. Geomorfologi Pantai. Dinamika Pantai. Fakultas Geografi UGM. Yogyakarta.

Suripin. 2004. Pelestarian Sumber Daya Tanah dan Air. Andi Offset. Yogyakarta.

Triatmodjo, B. 2010. Hidrologi Terapan. Yogyakarta : Beta Offset. 